\title{
Encontro Fazendo Gênero publica estudos sobre feminismo e gênero
}

\author{
Genealogias do silêncio: \\ feminismo e gênero.
}

RIAL, Carmen Sílvia Moraes; TONELI, Maria J uracy Filgueiras (Orgs.).

Floria nópolis: Ed. Mulheres, 2004. 198 p.

Em 1994 começou-se a organizar, pela Universidade Federal de Santa Catarina, um evento bienal denominado Fazendo Gênero, onde pesquisadoras e pesquisadores brasileiros e estrangeiros que trabalham no campo dos estudos de gênero e dos estudos feministas vêm se encontrar para apresentações de suas pesquisa e debates em diferentes âmbitos. De lá para cá esses encontros têm gerado várias public a ções com coletâneas de vá rios trabalhos apresentados pelos seus participantes. 0 exemplarque tenho em minhas mãosé o volume que reúne alguns dos artigos apresentados nos encontros Fazendo Gênero de 2000 e $2002 .{ }^{1}$

Conforme comentam as organizadoras do volume, os estudos de gênero e feminista s estã o amplamente consolidados no Brasil, especia Imente na Universida de Federal de Santa Catarina (UFSC), que tem um interesse particular nessa área de estudos no país, contando com ma is de 30 professoras doutoras que se dedicam a pesquisa s no setor. Desde 1999 é na UFSC que um grupo de professoras se dedica à edição da Revista Estudos Feministas, public a ção a lta mente conceituada tanto no Brasil como também no exterior. Todas essas referências nos asseguram que a criação deste volume vem de acadêmic as de a ltíssima qualidade.

O tema do encontro rea liza do no a no 2000 girou em tomo de "Cultura, polític a e sexualida de no século XXI", o que ampliou o alcance do projeto, tendo como objetivo a realiza ção de um 
balanço do século XX na área de estudos de gênero e feministas assim como deba te sobre as perspectivas para o século XXI (p. 9). Além das participantes nacionais, renomadas pesquisadoras da Europa, Estados Unidos e América Latina participaram do evento.

o livro é aberto com o trabalho apresentado pela mais respeitada antropóloga francesa contemporânea, Françoise Héritier, substituta de Lévi-Straussna direção do importante Laboratório de Antropologia Social do Centre National de la Recherche Scientifique assim como a primeira e única mulher antropóloga a ser admitida no Collège de France. Seguindo um marco teórico estruturalista preferido por ela durante décadas, Héritier faz um balanço em termos históricos da condição universal da submissão da mulher e discute atentamente a revolução contraceptiva nos últimos 40 anos. A palestra que impressionou e lotou o auditório daquela noite - conforme é comentado na introdução - "apontou para uma drástica a lteração destas relações de poder envolvendo os sexos" (p. 10).

A queda na taxa de crescimento populacional em diversos países - sejam eles desenvolvidos, sejam os considerados pobres não é movida pelos mesmos motivos. Conectando-se ao tema tratado por Françoise Héritier, a historiadora Joana Maria Pedro prossegue apresentando seu estudo sobre as polític as de controle de natalidade em países da América Latina, Europa e Estados Unidos. Ela mostra que as dinâmicas que incentiva ram o uso do anticoncepcional e a queda da natalidade em países considerados ricos são bastante distintas da quelas dos ma is pobres. Passando do Brasil para o Uruguai, temos a seguir um texto em espanhol escrito pela historiadora Graciela Sapriza, que ta mbém aborda o tema do corpo e da sexualidade. Sapriza expõe que o debate sobre a sexualidade tomou maiores proporções na década de 1930, quando o govemo a provou leis permitindo o aborto. Na época, os setores católicos e conservadores se dedicaram a modificar a referida cláusula que durou apenas quatro anos. Ao longo do século XX outras leis foram criadas definindo a condição da mulher no país, o que revelou, nessa trajetória, choques e oposições existentes entre a Igreja e as feministas.

Com uma a proximação psicanalítica, Rafael Andrés Villari utiliza o romance de Marguerite Duras Le ravissement de Lا V. Stein, em que ele estuda as vozes femeninas do texto e suas expressões de dor e sofrimento. A seguir,
Mara Coelho Lago, com base na teoria de psicanalistas de peso, aborda conceitos de identidade e sujeito, fazendo assim um diálogo entre a psicanálise e outras ciências humanas. Seguindo também passos psicanatíticos, Oscar Reymundo nos fala sobre "Novas famílias, novas implicações éticas" e ilustra sua a presentação com o caso específico de uma criança que enfrenta várias dificuldades ao se mudar para um novo meio social, nova escola, novosa migos, e com a mãe adotiva que mantém um relacionamento amoroso com outra mulher. Os próximos dois textos também tocam o tema das "novas famílias": Miriam Pillar Grossi aborda o tema das famílias homossexua is e Luciana Hartmann faz uma incursão pelo mundo rural gaúcho estudand o a na rrativa oral das mulheres da região. Outra experiência rural nos é narrada por Alai Garcia Diniz atra vés de um estudo realizado com um grupo de mulheres do Movimento dos Trabalhadores Rura is Sem Terra, revelando a inquestionável liderança existente nesse meio, assim como sugerindo o dilema do diálogo entre academia e militância.

Sandra Maria da Mata Azerêdo, inspirada em teorias da psicanálise, da antropologia e dos estud os cultura is, faz um estudo sobre a violência nas delegacias de mulheres de Belo Horizonte, observando as diferenças entre violência e poder. A pesquisa etnográfica também é base para o artigo de Cláudia Voigt Espínola, que realiza um estudo sobre as mulheres muçulmanas de Florianópolis e o crescente uso do véu após o atentado de 11 de setembro, o que revela ma is um símbolo de pertencimento do que de op ressão.

Tânia Regina Oliveira Ramos vai desvendar dentro da literatura uma linha de personagens femininas que chamam a atenção para o que está a contec endo com a mulherneste século XXI. Ela trata do corpo e ma is especificamente do corpo gordo, discutindo as forçadas transformações pedidas pela sociedade e o freqüente drama do corpo gordo que sofre para alcançar estereótipos de estética sociais. A litera tura ta mbém é o pano de fundo do trabalho de Rachel Soihet, que estuda as profissões exercidas pelas personagens de parte da obra de Júlia L. de Almeida, indicando mudanças e avanços na consciência de gênero.

Aárea da saúde é tocada porRogerio Lopes Azize que, a partir de uma ótica antropológica, trata dos signific a dos a tribuíd os a o uso do Viagra. Azize apresenta os discursos de usuários e de membros do campo biomédico e conclui que o uso do remédio "parece confimare re-configurar 
uma 'masculinidade ansiosa'" (p. 180). 0 último texto, de autoria de Tania Navarro Swain, fecha a coletânea fazendo um elo de ligação com o que foi exposto porFrançoise Héritier. Swa in utilizase de teorias feministas distintase indaga sobre o signific a do social da diferença sexual, do corpo e do sexo.

A obra é farta de artigos de qualidade, mostrando que o mundo acadêmico brasileiro, representado aqui por profissiona is de alto gabarito, não fic a nada a trás dos intemacionais. Podemos a plaudir de pé o êxito da Universidade Federal de Santa Catarina com a organização desses encontros para o debate dos estudos feministas e de gênero. Os frutos, muito bem colhidos, estão organizados aqui com esmero para a a preciação do público interessado.

\section{Notas}

${ }^{1}$ Esta resenha foi publicada primeiramente na revista ellipsis - Joumal of the American Portuguese Studies Association (v. 4, 2006, p. 187-190) e está sendo republicada com a licença do editore da autora.

Debora Cordeiro Rosa Florida State University 